\title{
Ambidextrous Innovation in Mediating Entrepreneurial Creativity on Firm Performance and Competitive Advantage
}

\author{
Eduard Alfian Syamsya SIJABAT ${ }^{1}$, Umar NIMRAN $^{2}$, Hamidah Nayati UTAMI ${ }^{3}$, Arik PRASETYA ${ }^{4}$ \\ Received: August 01, 2020 Revised: October 05, 2020 Accepted: October 15, 2020
}

\begin{abstract}
A new business venture faces intense competition in a dynamic environment. To survive, new business ventures and established companies both need to generate creativity and significant new ventures to be highly competitive and have high levels of performance. In this study, we examined new business ventures that determined their competitiveness and performance generated from entrepreneurial creativity and mediated by ambidextrous innovation. This research used survey data collected from 143 Indonesian's new business shipping agencies, which was collected using an online survey and analyzed through structural equation modeling. The results showed that entrepreneurial creativity in new business ventures is positively associated with competitive advantage but not significant to create a competitive advantage. In contrast, entrepreneurial creativity is positively associated with firm performance. This result indicates that efforts to generate entrepreneurial creativity are not sufficient to create a competitive advantage despite having a significant influence on firm performance. However, entrepreneurial creativity is significantly and positively associated with firm performance and competitive advantage when mediated by ambidextrous innovation. The findings of this study suggest that the competitive advantage of a new business venture in facing intense competition in a dynamic environment condition can be overcome by generating strategic action in the form of entrepreneurial creativity and ambidextrous innovation.
\end{abstract}

Keywords: New Business Venture, Entrepreneurial Creativity, Ambidextrous Innovation, Competitive Advantage

JEL Classification Code: M10, M13

\section{Introduction}

Entrepreneurial creativity is a combination of creativity and entrepreneurship. It creates original ideas and significant new ventures that are crucial for a company. New ventures generated by entrepreneurial creativity are in the form

${ }^{1}$ First Author and Corresponding Author. Business Administration Doctoral Program, Faculty of Administrative Sciences, Brawijaya University, Malang, Indonesia [Postal Address: Samudera Indonesia Bldg 3rd Fl. Jl Letjen S. Parman Kav 35., Jakarta, 11480, Indonesia] Email: eduard.a.s.sijabat@gmail.com; eduardsijabat@student.ub.ac.id 2Professor, Faculty of Administrative Sciences, Brawijaya University, Malang, Indonesia. Email: umar_n_fia@ub.ac.id

${ }^{3}$ Associate Professor, Faculty of Administrative Sciences, Brawijaya University, Malang, Indonesia. Email: hamidahn@ub.ac.id

${ }^{4}$ Assistant Professor, Faculty of Administrative Sciences, Brawijaya

University Malang, Indonesia. Email: arik_p_fia@ub.ac.id

(c) Copyright: The Author(s)

This is an Open Access article distributed under the terms of the Creative Commons Attribution Non-Commercial License (https://creativecommons.org/licenses/by-nc/4.0/) which permits unrestricted non-commercial use, distribution, and reproduction in any medium, provided the original work is properly cited. of new business processes and programs for distributing products or services to customers (Amabile, 1997). Entrepreneurial creativity at the organizational level is a crucial factor in responding to intense business competition. Companies that manage creativity have a significantly higher profit and turnover than companies lacking creativity management (Madzar \& Ines, 2019). This finding indicated that entrepreneurial competitiveness is associated with firm performance. Creativity through the generation of original ideas and new ventures encourages a company to improve its competitiveness continuously (Barriopedro, Ripol, \& Pesantez, 2019).

In contrast to empirical studies of entrepreneurial creativity at the individual or employee level, empirical studies of entrepreneurial creativity at the organizational level are rare. Empirical assessments of the relationship between entrepreneurial creativity and firm performance and the relationship between entrepreneurial creativity and the firm's competitive advantage are similarly limited. The available empirical studies were conducted on established manufacturing companies. Established companies with 
sufficient resources and market access have demonstrated that entrepreneurial creativity improves firm performance (Samson \& Umar, 2020). It has been suggested that access to external resources is a competitiveness factor (Kathiravan et al., 2019). In contrast, new business ventures have limited access to resources, markets, legitimacy, and reputation (Larraneta, Zahra, \& Bonzalez, 2012). In the highly competitive and dynamic environment of the business sector, both established companies and new business ventures are treated the same. Companies need to generate entrepreneurial creativity and innovative breakthroughs to maintain their competitive advantage and achieve a sustainable firm performance. Companies need creativity and innovation to continuously maintain their competitiveness (Carrier, Cossette, \& Verstraete, 1999). Creativity and innovation play a role in generating a firm's competitive advantage (Gupta \& Banerjee, 2016).

Entrepreneurial creativity generates original ideas and significant new ventures, which are precursors to producing innovative breakthroughs as a response to competitive challenges. Entrepreneurs create corporate value through innovative breakthroughs that generate new opportunities, products, and services (Eftekhari \& Bogers, 2015).

Established companies generate significant innovation by generating entrepreneurial creativity, but new business ventures do not generate significant innovation (Heunk, 1998). In contrast, Baron and Tang (2011) found that new business ventures produced radical innovation by generating entrepreneurial creativity. Other empirical studies have shown that both established companies and new business ventures that have an innovation culture that is significantly associated with the firm's competitiveness and the improvement in firm performance. However, a new business venture has limited resources and lower market access than an established company (Bibi et al., 2020).

Several previous empirical studies have found a significant positive relationship between entrepreneurial creativity and firm performance and competitive advantage in established companies. However, it is unclear if these correlations hold for new business ventures. Our research fills this gap by investigating whether the entrepreneurial creativity of a new business venture is capable of creating ambidextrous innovation that leads to competitive advantages and high performance for the company in a volatile and uncertain environment condition.

Our paper was adapted from a previous empirical model of correlation between entrepreneurial creativity, firm performance, and competitive advantage. The model was modified to determine whether ambidextrous innovation mediated the correlation between entrepreneurial creativity and firm performance, and the correlation between entrepreneurial creativity and competitive advantage. We contribute new findings regarding the role of entrepreneurial creativity, mediated by ambidextrous innovation, in the performance and competitive advantage of new business ventures.

\section{Literature Review}

\subsection{Entrepreneurial Creativity and Competitive Advantage}

The competitiveness, or competitive advantage, of a company, is based on corporate resource empowerment. One aspect of this empowerment is to foster the generation of new creative ideas and ventures. Companies with a creative culture have more competitive advantages than competitors which lack creativity (Woodman, Sawyer, \& Ricky, 1993). Studies of the correlation between entrepreneurial creativity and competitive advantage are rarely available. Besides, these correlations that have been conducted involved established manufacturing companies. Entrepreneurial creativity was found to have a significant influence on the company's competitive advantage (Kathiravan et al., 2019). New business ventures generate original creative ideas and significant new ventures as a response to intense competition and to maintain the sustainability of the company. Furthermore, the more original the creative ideas and new ventures, the greater the competitive advantage. Consequently, we propose the hypothesis:

H1: Entrepreneurial creativity is positively associated with competitive advantage

\subsection{Entrepreneurial Creativity and Firm Performance}

There have been studies of the relationships between creativity, employee performance, and firm performance, especially in terms of employee creativity. Creativity efforts by employees are important contributions to firm performance (Redmond, Mumford, \&Teach, 1993). Products and services designed to be novel improve the performance of mediumand small-scale companies (Andrews \& Smith, 1996). Entrepreneurial creativity is synonymous with original creative ideas and significant new ventures generated by managing creativity. Companies employing creativity management have higher turnovers and profits than companies lacking structured creativity management (Madzar \& Ines, 2019). Furthermore, an assessment of the relationship between entrepreneurial creativity and firm performance in medium- and small-scale companies found that the generation of original creative ideas and significant new ventures influence firm performance (Samson \& Umar, 2019). Business ventures involving new services generate original creative ideas and new ventures that improve firm performance. Therefore, the level of activity in generating original creative ideas and new ventures reflects an improvement in firm performance. Therefore we propose the hypothesis:

H2: Entrepreneurial creativity is positively associated with firm performance 


\subsection{Entrepreneurial Creativity and Ambidextrous Innovation}

A previous empirical study of established companies found that there was a significant relationship between entrepreneurial creativity and innovation and established companies generated significant innovation (Heunk, 1998). The effect of the age and size of the company on the entrepreneurial creativity and innovation have also been investigated. Entrepreneurial creativity in new companies had a significant effect on radical innovation (Baron \& Tang, 2011), and entrepreneurial creativity affected both process innovation and product innovation in established companies (Ahlin, Mateja, \& Ribert, 2013). A study of medium- and small-scale companies found that entrepreneurial creativity influenced innovation (Noor, Musa, \& Yaco, 2018). New companies face intense competition and a dynamic environment. To maintain the company's sustainability, in addition to producing radical (exploratory) innovative breakthroughs, it must produce exploitative innovations. This balance between exploitative and exploratory innovations is known as ambidextrous innovation. Therefore, we propose the hypothesis:

H3: Entrepreneurial creativity is positively associated with ambidextrous innovation

\subsection{Ambidextrous Innovation and Firm Performance}

A company continuously introduces new technological innovations to its products and services solely to maintain a satisfactory firm performance (Damanpour, Walker, \& Avellaneda, 2009). Research on medium- and smallscale companies found that innovation had a positive and significant impact on firm performance (Lestari et al., 2020). Other empirical evidence showed that innovation capability also had a positive relationship with firm performance (Hoang \& Ngoc, 2019) and the innovation process also had a positive effect on firm performance (Muafi et al., 2020). Other research on medium- and small scale-companies showed that ambidextrous innovation had a significant effect on firm performance (Acosta, Popa, \& Isabel, 2018). Furthermore, research on restaurant service companies (Cho, Bonn, \& Han, 2019) showed that a startup company seeks to balance exploitative innovation and exploratory innovation. However, the study found that this balance did not have a significant effect on the performance of established companies. Exploitative innovation is crucial for new companies, and exploratory innovation is crucial for established companies. Other empirical studies found that new business ventures by established companies with an innovation climate (shown by its management of human resources), were positively correlated with firm performance (Bibi et al., al, 2020). A new business venture offering a service in an intensely competitive environment requires ambidextrous innovation to generate a sustainable firm performance. A higher rate of ambidextrous innovation breakthroughs increases firm performance. Therefore, we propose the hypothesis:

H4: Ambidextrous innovation is positively associated with firm performance

\subsection{Ambidextrous Innovation and Competitive Advantage}

Responsiveness to the change of environment is associated with the competitiveness of the company (Nguyen \& Khoa, 2020). Innovative companies are more flexible and have a greater capacity to adapt to change. This adaptive capability is pursued through radical or exploratory innovation breakthroughs and incremental or exploitative innovations. Companies with an innovation climate, in the form of human resources supporting a culture of innovation, had a positive correlation with the company's competitiveness (Bibi et al., 2020). Company breakthroughs in innovation in response to environmental changes is a form of balance between exploratory innovation and exploitative innovation. A successful company with a competitive advantage is a company that can strike a balance between exploitative innovation and exploratory innovation (Chang \& Hughes, 2012). Research on established manufacturing companies found that exploratory and exploitative service breakthroughs had a significant effect on competitive advantage (Liu \& Huang, 2018). A new business venture needs ambidextrous innovation to gain a competitive advantage. Furthermore, more ambidextrous innovation would increase the company's competitive advantage. Therefore, we propose the hypothesis:

H5: Ambidextrous innovation is positively associated with competitive advantage

\subsection{Firm Performance and Competitive Advantage}

Firm performance and competitive advantage have an equivalent relationship (Newbert, 2008). Superior firm performance indicates a competitive advantage, and a company with a competitive advantage indicates superior firm performance. However, further research found that the relationship between firm performance and competitive advantage was not always equivalent (Sigallas \& Papadakis, 2018). Competitive advantage does not always indicate superior firm performance and vice versa. Other empirical studies showed that firm performance has a significant effect on competitive advantage (Jamshi \& Ganeskhumar, 2017). Furthermore, firm performance in the form of customer 
satisfaction and operational performance has a significant effect on competitive advantage (Kharub \& Sharma, 2018). Therefore we propose the hypothesis:

H6: Company performance is positively associated with competitive advantage

\subsection{Ambidextrous Innovation Mediation}

Innovative companies or companies having a climate of innovation have an advantage when facing competition. Breakthroughs in innovation can be turned into a competitive advantage and improved firm performance (Bibi et al., 2020). There is no empirical evidence for ambidextrous innovation playing a mediating role in the relationship between creativity and competitive advantage. Research on the role of ambidextrous innovation in mediating the relationship between entrepreneurial creativity and firm performance found a positive significant correlation (Ferreira, Arnold, \& Luiz, 2018). The medium- and small-scale companies needed entrepreneurial creativity at a certain level to develop the company's capability. Entrepreneurial creativity can facilitate the development of innovation (Subramanian \& Youndt, 2005). Through entrepreneurial creativity, mediumand small-scale companies can accelerate the development of new products and services and create innovative products (Chen \& Huang, 2009). New business ventures with a climate of innovation encourage the generation and development of original, creative ideas and significant new ventures. The development of creative ideas and new ventures are implemented through innovative breakthroughs. In turn, the innovative breakthroughs improved firm performance in the form of special strategic changes. These strategic changes were not easily imitated by competitors and became a competitive advantage. Therefore, we propose the hypothesis:

H7a: Ambidextrous innovation positively mediates the relationship between entrepreneurial creativity and competitive advantage.

H7b: Ambidextrous innovation positively mediates the relationship between entrepreneurial creativity and firm performance

\section{Research Methods}

\subsection{Sample and Data Collection}

This study was explanatory research using a quantitative method approach. The research studied Indonesian shipping agencies that were members of the Indonesian Ship Agency Association (ISAA). Shipping agencies are service companies engaged in managing foreign and domestic vessels in Indonesian seaports. The research was conducted over three months (March-May) in 2020. The research population was shipping agencies that were members of the ISAA. In February 2020 , there were 512 shipping agencies in Indonesia, of which 220 (registered in 22 of the 34 Indonesian provinces) were members of ISAA. The sample was determined with the Slovin formula, with an error tolerance level of $5 \%$. The sample comprised 143 companies from a population of 220 companies. The number of companies in each province was proportional to the total company population of the respective provinces. The sample comprised organizations represented by the director or general manager, who were assumed to be the most knowledgeable about company-related issues. The sampling technique was carried out by randomly drawing lots. The research instrument used was a questionnaire constructed from item descriptions that acted as indicators for the research variables. The questionnaire was distributed to the target participants using a google document survey link online. It was supplemented by a long-distance interview aimed at confirming the accuracy and completeness of the data. The measurement scale was a six-point Likert interval scale (1. strongly disagree, 2 . disagree, 3 . slightly disagree, 4 . slightly agree, 5 . agree, and 6 . strongly agree).

\subsection{Measurement}

The measurement of the research variables was based on the framework of the research constructs which consisted of four variables - one exogenous variable (Entrepreneurial Creativity) and endogenous variables (Ambidextrous Innovation, Firm Performance, and Competitive Advantage). The study framework used a second-order depth level. The variable entrepreneurial creativity has two indicators - originality and new venture significance. Each of these indicators has four items adapted from Hills, Lumpkin, and Singh (1997) and Puhakka (2005). The variable ambidextrous innovation has two indicators - exploitative innovation and exploratory innovation. Each of these indicators has four items adapted from Atuahene-Gima (2005) and He and Wong (2004). The variable firm performance has four indicators finance, customers, business processes, and learning growth. Each of these indicators has three items adapted from Sigalas (2015). The variable competitive advantage has two indicators - taking advantage of opportunities and neutralizing threats. Each of these indicators has four items adapted from Sigalas, Pekka, \& Georgopoulos (2013). The description of the items for each indicator was developed into a questionnaire.

\subsection{Analysis Method}

Validity and reliability tests were performed for items and descriptive analysis of responses using SPSS 18.0. Factor analysis and research model analysis were performed (convergent validity, discriminant validity, composite reliability, the goodness of fit, and the research hypotheses) using the SEM WarPLS 7 series software. 


\section{Results}

Pre instrument test distributed to 30 companies - the validity test showed that the items for the four variables had a Pearson correlation above 0.3 , and the reliability test showed that all of the items for the four variables had Cronbach's alpha coefficient values above 0.6 . Therefore, all items were declared valid and reliable.

\subsection{Respondent Profile}

The respondents were new shipping agencies, of which $71.9 \%$ of the companies are less than 3 years old, of which $83.3 \%$ have fewer than 25 employees, and of which, $76.3 \%$ have fewer than three branch offices. In general, the respondents were new business ventures with a small number of employees and regional service coverage networks.

\subsection{Validity and Reliability}

Validity and reliability tests were carried out to confirm the instrument validity and reliability found in the pretest. The convergent validity test as shown in Table 1 showed that all items, indicators had a loading factor value above 0.60 that met the convergent validity requirements.

Table 1: Item and Indicator Convergent Validity

\begin{tabular}{|c|c|c|c|c|c|c|}
\hline Variable & Indicator & Loading Factor & Item & Loading Factor & P-value & Description \\
\hline \multirow{8}{*}{$\begin{array}{l}\text { Entrepreneurial } \\
\text { Creativity }\left(X_{1}\right)\end{array}$} & \multirow{4}{*}{ Originality $\left(\mathrm{X}_{1.1}\right)$} & \multirow{4}{*}{0.954} & $X_{1.1 .1}$ & 0.876 & $<0.001$ & Valid \\
\hline & & & $X_{1.1 .2}$ & 0.838 & $<0.001$ & Valid \\
\hline & & & $X_{1.1 .3}$ & 0.917 & $<0.001$ & Valid \\
\hline & & & $X_{1.1 .4}$ & 0.893 & $<0.001$ & Valid \\
\hline & \multirow{4}{*}{$\begin{array}{l}\text { New Venture } \\
\text { Significance }\left(X_{1.2}\right)\end{array}$} & \multirow{4}{*}{0.954} & $X_{1.2 .1}$ & 0.916 & $<0.001$ & Valid \\
\hline & & & $X_{1.2 .2}$ & 0.898 & $<0.001$ & Valid \\
\hline & & & $\mathrm{X}_{1.2 .3}$ & 0.895 & $<0.001$ & Valid \\
\hline & & & $X_{1.2 .4}$ & 0.786 & $<0.001$ & Valid \\
\hline \multirow{8}{*}{$\begin{array}{l}\text { Ambidextrous } \\
\text { Innovation }\left(\mathrm{Y}_{1}\right)\end{array}$} & \multirow{4}{*}{$\begin{array}{l}\text { Exploitative } \\
\text { Innovation }\left(\mathrm{Y}_{1.1}\right)\end{array}$} & \multirow{4}{*}{0.938} & $Y_{1.1 .1}$ & 0.817 & $<0.001$ & Valid \\
\hline & & & $Y_{1.1 .2}$ & 0.890 & $<0.001$ & Valid \\
\hline & & & $Y_{1.1 .3}$ & 0.845 & $<0.001$ & Valid \\
\hline & & & $Y_{1.1 .4}$ & 0.815 & $<0.001$ & Valid \\
\hline & \multirow{4}{*}{$\begin{array}{l}\text { Exploratory } \\
\text { Innovation }\left(\mathrm{Y}_{1.2}\right)\end{array}$} & \multirow{4}{*}{0.938} & $Y_{1.2 .1}$ & 0.903 & $<0.001$ & Valid \\
\hline & & & $Y_{1.2 .2}$ & 0.897 & $<0.001$ & Valid \\
\hline & & & $Y_{1.2 .3}$ & 0.893 & $<0.001$ & Valid \\
\hline & & & $Y_{1.2 .4}$ & 0.828 & $<0.001$ & Valid \\
\hline \multirow{12}{*}{$\begin{array}{l}\text { Firm } \\
\text { Performance } \\
\left(\mathrm{Y}_{2}\right)\end{array}$} & \multirow{3}{*}{ Finance $\quad\left(Y_{2.1}\right)$} & \multirow{3}{*}{0.853} & $Y_{2.1 .1}$ & 0.925 & $<0.001$ & Valid \\
\hline & & & $Y_{2.1 .2}$ & 0.934 & $<0.001$ & Valid \\
\hline & & & $Y_{2.1 .3}$ & 0.860 & $<0.001$ & Valid \\
\hline & \multirow{3}{*}{ Customer $\quad\left(\mathrm{Y}_{2.2}\right)$} & \multirow{3}{*}{0.918} & $Y_{2.2 .1}$ & 0.888 & $<0.001$ & Valid \\
\hline & & & $Y_{2.2 .2}$ & 0.882 & $<0.001$ & Valid \\
\hline & & & $Y_{2.2 .3}$ & 0.841 & $<0.001$ & Valid \\
\hline & \multirow{3}{*}{$\begin{array}{l}\text { Business Process } \\
\left(Y_{2.3}\right)\end{array}$} & \multirow{3}{*}{0.895} & $Y_{2.3 .1}$ & 0.881 & $<0.001$ & Valid \\
\hline & & & $Y_{2.3 .2}$ & 0.906 & $<0.001$ & Valid \\
\hline & & & $Y_{2.3 .3}$ & 0.888 & $<0.001$ & Valid \\
\hline & \multirow{3}{*}{$\begin{array}{l}\text { Growth \& Learning } \\
\left(Y_{2.4}\right)\end{array}$} & \multirow{3}{*}{0.898} & $Y_{2.4 .1}$ & 0.891 & $<0.001$ & Valid \\
\hline & & & $Y_{2.4 .2}$ & 0.874 & $<0.001$ & Valid \\
\hline & & & $Y_{2.4 .3}$ & 0.871 & $<0.001$ & Valid \\
\hline
\end{tabular}


Table 1: Continued

\begin{tabular}{|c|c|c|c|c|c|c|}
\hline Variable & Indicator & Loading Factor & Item & Loading Factor & P-value & Description \\
\hline \multirow{8}{*}{$\begin{array}{l}\text { Competitive } \\
\text { Advantage }\left(\mathrm{Y}_{3}\right)\end{array}$} & \multirow{4}{*}{$\begin{array}{l}\text { Take Advantage of } \\
\text { Opportunity } \\
\left(\mathrm{Y}_{3.1}\right)\end{array}$} & \multirow{4}{*}{0.944} & $\mathrm{Y}_{3.1 .1}$ & 0.867 & $<0.001$ & Valid \\
\hline & & & $Y_{3.1 .2}$ & 0.825 & $<0.001$ & Valid \\
\hline & & & $Y_{3.1 .3}$ & 0.848 & $<0.001$ & Valid \\
\hline & & & $Y_{3.1 .4}$ & 0.877 & $<0.001$ & Valid \\
\hline & \multirow{4}{*}{$\begin{array}{l}\text { Neutralize Threat } \\
\left(Y_{3.2}\right)\end{array}$} & \multirow{4}{*}{0.944} & $\mathrm{Y}_{3.2 .1}$ & 0.852 & $<0.001$ & Valid \\
\hline & & & $Y_{3.2 .2}$ & 0.898 & $<0.001$ & Valid \\
\hline & & & $\mathrm{Y}_{3.2 .3}$ & 0.877 & $<0.001$ & Valid \\
\hline & & & $Y_{3.2 .4}$ & 0.900 & $<0.001$ & Valid \\
\hline
\end{tabular}

The discriminant validity test as shown in Table 2 showed that all items and all indicators for each variable had an average variance extracted (AVE) above 0.5 and therefore fulfilled the condition for discriminant validity. If the loading factor is above 0.60 and the probability ( $p$-value) is less than $5 \%$ then the item or indicator is valid (Hair, Anderson, \& Tatham, 2011). The reliability test as shown in Table 3 showed that four variables had Cronbach's alpha values above 0.70 and composite reliability values above 0.60 that meet the reliability requirements. If the value of Cronbach's alpha coefficient is above 0.70 and the value of the reliability coefficient is above 0.60 then the variable is declared reliable (Hair, Anderson \& Tatham, 2011).

\subsection{The Goodness of Fit}

The goodness of fit was assessed using R-squared (the proportion of endogenous variables explained by exogenous variables) and Q-squared, which measures the relevance of a set of exogenous latent variables to endogenous variables. The test results are shown in Table 4 showed that the R-squared values of the four variables were above 0.67 , which indicated strong correlations and the Q-squared value of the four variables was above 0.35 which indicated a better data fit. The final step in evaluating the feasibility of the model was conducting the goodness of fit test using the WarPLS approach as shown in Table 5 showed that all indicators met the goodness of fit criteria. Therefore, we concluded that the research model fulfilled the goodness of fit requirements.

\subsection{Hypothesis Test}

The hypothesis test as shown in Table 6 found that of the eight hypotheses, there was one unsupported hypothetical relationship between variables. The relationship between entrepreneurial creativity and competitive advantage had a positive relationship but not significant, therefore, $\mathrm{H} 1$ was rejected. The relationship between entrepreneurial
Table 2: Item and Indicator Discriminant Validity

\begin{tabular}{|c|c|c|c|c|}
\hline Variable & AVE & Indicator & AVE & Description \\
\hline \multirow[b]{2}{*}{$\begin{array}{l}\text { Entre- } \\
\text { preneurial } \\
\text { Creativity }\left(X_{1}\right)\end{array}$} & \multirow[b]{2}{*}{0.911} & $\begin{array}{l}\text { Originality } \\
\left(\mathrm{X}_{1.1}\right)\end{array}$ & 0.777 & Valid \\
\hline & & $\begin{array}{l}\text { Significance } \\
\text { of new } \\
\text { business } \\
\left(X_{1.2}\right)\end{array}$ & 0.766 & Valid \\
\hline \multirow{2}{*}{$\begin{array}{l}\text { Ambidextrous } \\
\text { Innovation } \\
\left(\mathrm{Y}_{1}\right)\end{array}$} & \multirow{2}{*}{0.879} & $\begin{array}{l}\text { Exploitative } \\
\text { Innovation } \\
\left(\mathrm{Y}_{1.1}\right)\end{array}$ & 0.709 & Valid \\
\hline & & $\begin{array}{l}\text { Explorative } \\
\text { Innovation } \\
\left(Y_{1.2}\right)\end{array}$ & 0.776 & Valid \\
\hline \multirow{4}{*}{$\begin{array}{l}\text { Firm } \\
\text { Performance } \\
\left(\mathrm{Y}_{2}\right)\end{array}$} & \multirow{4}{*}{0.794} & $\begin{array}{l}\text { Finance } \\
\left(Y_{2.1}\right)\end{array}$ & 0.822 & Valid \\
\hline & & $\begin{array}{l}\text { Customers } \\
\left(Y_{2.2}\right)\end{array}$ & 0.758 & Valid \\
\hline & & $\begin{array}{l}\text { Business } \\
\text { Process } \\
\left(\mathrm{Y}_{2.3}\right)\end{array}$ & 0.795 & Valid \\
\hline & & $\begin{array}{l}\text { Growth \& } \\
\text { Learning } \\
\left(Y_{2.4}\right)\end{array}$ & 0.772 & Valid \\
\hline \multirow{2}{*}{$\begin{array}{l}\text { Competitive } \\
\text { Advantage } \\
\left(\mathrm{Y}_{3}\right)\end{array}$} & \multirow[t]{2}{*}{0.891} & $\begin{array}{l}\text { Take } \\
\text { Advantage } \\
\text { of } \\
\text { Opportunity } \\
\left(Y_{3.1}\right)\end{array}$ & 0.730 & Valid \\
\hline & & $\begin{array}{l}\text { Neutralize } \\
\text { Threats } \\
\left(Y_{3.2}\right)\end{array}$ & 0.777 & Valid \\
\hline
\end{tabular}


creativity and firm performance and the relationship between entrepreneurial activity and ambidextrous innovation was significant. Therefore, $\mathrm{H} 2$ and $\mathrm{H} 3$ were accepted. The influence of ambidextrous innovation on firm performance and the influence of ambidextrous innovation on competitive advantage was also significant. Therefore, H4 and H5 were accepted. The relationship between firm performance and competitive advantage was significant. Therefore, H6 was accepted. The indirect relationships between entrepreneurial creativity and firm performance and between entrepreneurial creativity and competitive advantage, when mediated by ambidextrous innovation, were positive and significant. Therefore, $\mathrm{H} 7 \mathrm{a}$ and $\mathrm{H} 7 \mathrm{~b}$ were accepted. The role of ambidextrous innovation in mediating the relationship between entrepreneurial creativity and firm performance was as a partial mediating variable, as shown by the significant relationship between the two mediated variables. The role of ambidextrous innovation in mediating entrepreneurial creativity and competitive advantage was as a complete mediating variable.

Table 3: Composite Reliability and Cronbach's Alpha

\begin{tabular}{|c|c|c|c|c|c|c|}
\hline Variable & $\begin{array}{l}\text { Composite } \\
\text { Reliability }\end{array}$ & $\begin{array}{c}\text { Cronbach's } \\
\text { alpha }\end{array}$ & Indicator & $\begin{array}{c}\text { Composite } \\
\text { Reliability }\end{array}$ & $\begin{array}{c}\text { Cronbach's } \\
\text { alpha }\end{array}$ & Description \\
\hline \multirow{2}{*}{ Entrepreneurial Creativity $\left(\mathrm{X}_{1}\right)$} & \multirow{2}{*}{0.953} & \multirow{2}{*}{0.902} & $X_{1.1}$ & 0.933 & 0.904 & Reliable \\
\hline & & & $X_{1.2}$ & 0.929 & 0.897 & Reliable \\
\hline \multirow{2}{*}{ Ambidextrous Innovation $\left(Y_{1}\right)$} & \multirow{2}{*}{0.936} & \multirow{2}{*}{0.862} & $Y_{1.1}$ & 0.907 & 0.863 & Reliable \\
\hline & & & $Y_{1.2}$ & 0.933 & 0.903 & Reliable \\
\hline \multirow{3}{*}{ Firm Performance $\left(\mathrm{Y}_{2}\right)$} & \multirow{3}{*}{0.939} & \multirow{3}{*}{0.914} & $Y_{2.1}$ & 0.933 & 0.891 & Reliable \\
\hline & & & $Y_{2.2}$ & 0.904 & 0.840 & Reliable \\
\hline & & & $Y_{2.3}$ & 0.921 & 0.871 & Reliable \\
\hline \multirow{2}{*}{ Competitive Advantage $Y_{3}$ ) } & \multirow{2}{*}{0.942} & \multirow{2}{*}{0.877} & $Y_{3.1}$ & 0.915 & 0.877 & Reliable \\
\hline & & & $Y_{3.2}$ & 0.933 & 0.94 & Reliable \\
\hline
\end{tabular}

Table 4: The Goodness of Fit Structural Model

\begin{tabular}{|l|l|c|c|c|}
\hline No & \multicolumn{1}{|c|}{ Variable } & R-squared & Adjusted R-squared & Q-squared \\
\hline 1 & Entrepreneurial Creativity $\left(\mathrm{X}_{1}\right)$ & - & - & - \\
\hline 2 & Ambidextrous Innovation $\left(\mathrm{Y}_{1}\right)$ & 0.737 & 0.735 & 0.738 \\
\hline 3 & Firm Performance $\left(\mathrm{Y}_{2}\right)$ & 0.703 & 0.699 & 0.703 \\
\hline 4 & Competitive Advantage $\left(\mathrm{Y}_{3}\right)$ & 0.757 & 0.752 & 0.756 \\
\hline
\end{tabular}

Tabel 5: Model Fit and Quality Indices

\begin{tabular}{|l|l|l|l|c|}
\hline No & \multicolumn{1}{|c|}{ Model Fit and Quality indices } & \multicolumn{1}{|c|}{ Fit Criteria } & \multicolumn{1}{|c|}{ Result } & Description \\
\hline 1 & Average path coefficient (APC) & $\mathrm{p}<0.05$ & APC $=0.440 \quad p<0.001$ & Good \\
\hline 2 & Average R-squared (ARS) & $\mathrm{p}<0.05$ & ARS $=0.732 \quad p<0.001$ & Good \\
\hline 3 & Average Adjusted R-squared (AARS) & P $<0.05$ & AARS $=0.729 p<0.001$ & Good \\
\hline 4 & Average block VIF (AVIF) & Accepted if $\leq 5$ ideally $\leq 3.3$ & AVIF $=3.913$ & Good \\
\hline 5 & Average full collinearity VIF (AFVIF) & Accepted if $\leq 5$ ideally $<=3.3$ & AFVIF $=4.434$ & Good \\
\hline 6 & Tenenhaus GoF (GoF) & $\begin{array}{l}\text { Small } \geq 0.1 \text { medium }>=0.25 \\
\text { large }>=0.36\end{array}$ & GOF $=0.798$ & Ideal \\
\hline 7 & Sympson's paradox ratio (SPR) & Accepted if $\geq 0.7$ ideally $=1$ & SPR $=1.000$ & Ideal \\
\hline 8 & R-squared contribution ratio (RSCR) & Accepted if $\geq 0.9$, ideally $=1$ & RSCR $=1.000$ & SSR $=1.000$ \\
\hline 9 & Statistical suppression ratio (SSR) & Accepted if $\geq 0.7$ & NLBCDR $=1.000$ & Ideal \\
\hline 10 & $\begin{array}{l}\text { Nonlinear bivariate causality } \\
\text { direction ratio (NLBCDR) }\end{array}$ & Accepted if $\geq 0.7$ & \\
\hline
\end{tabular}


Table 6: Hypothesis Testing

\begin{tabular}{|l|c|c|c|c|c|}
\hline Hypothesis & $\begin{array}{c}\text { Inter variable } \\
\text { relationship }\end{array}$ & Path Coefficients & p-value & Description & Conclusion \\
\hline $\mathrm{H} 1$ & $\mathrm{X}_{1} \rightarrow \mathrm{Y}_{3}$ & 0.088 & $\mathrm{P}=0.143$ & Not significant & Rejected \\
\hline $\mathrm{H} 2$ & $\mathrm{X}_{1} \rightarrow \mathrm{Y}_{2}$ & 0.317 & $\mathrm{P}<0.001^{* *}$ & Significant & Accepted \\
\hline $\mathrm{H} 3$ & $\mathrm{X}_{1} \rightarrow \mathrm{Y}_{1}$ & 0.858 & $\mathrm{P}<0.001^{* *}$ & Significant & Accepted \\
\hline $\mathrm{H} 4$ & $\mathrm{Y}_{1} \rightarrow \mathrm{Y}_{3}$ & 0.352 & $\mathrm{P}<0.001^{* *}$ & Significant & Accepted \\
\hline $\mathrm{H} 5$ & $\mathrm{Y}_{1} \rightarrow \mathrm{Y}_{2}$ & 0,553 & $\mathrm{P}<0.001^{* *}$ & Significant & Accepted \\
\hline $\mathrm{H} 6$ & $\mathrm{Y}_{2} \rightarrow \mathrm{Y}_{3}$ & 0.475 & $\mathrm{P}<0.001^{* *}$ & Significant & Accepted \\
\hline $\mathrm{H} 7 \mathrm{a}$ & $\mathrm{X}_{1} \rightarrow \mathrm{Y}_{1} \rightarrow \mathrm{Y}_{3}$ & 0.452 & $\mathrm{P}<0.001^{* *}$ & Significant & Accepted \\
\hline $\mathrm{H} 7 \mathrm{~b}$ & $\mathrm{X}_{1} \rightarrow \mathrm{Y}_{1} \rightarrow \mathrm{Y}_{2}$ & 0.474 & $\mathrm{P}<0.001^{* *}$ & Significant & Accepted \\
\hline
\end{tabular}

Note : ** indicates significant on level $0.01(1 \%)$.

Analysis of the research model was conducted by determining the effect of the exogenous variables on the endogenous variables through an analysis of the results as a whole (not partially). The indirect effect and the total effect test of the exogenous variable of entrepreneurial creativity on the endogenous variable of competitive advantage had a path coefficient of 0.765 with a p-value $<0.001$. Therefore, the absolute contribution of entrepreneurial creativity to competitive advantage was $(0.762)^{2} \times 100 \%=$ $58 \%$. This finding indicated that entrepreneurial creativity accounted for $58 \%$ of the changes in the competitive advantage. Therefore, improving entrepreneurial creativity, ambidextrous innovation, and firm performance is crucial for improving competitive advantage.

\section{Discussion}

Efforts to generate original creativity (entrepreneurial creativity) and significant new ventures did not show a positive direct relationship. The influence of entrepreneurial creativity on competitive advantage was insignificant. This finding was not consistent with previous empirical studies that reported a significant positive and unidirectional relationship. This study indicated that this insignificant relationship was due to new business ventures having limited resources, limited access to external inputs, and lower corporate reputation compared with established companies. The effort to generate original creativity and significant new ventures is not sufficient to improve competitive advantage in an intensely competitive and dynamic environment. However, this study found that the relationship between entrepreneurial creativity and competitive advantage was mediated by ambidextrous innovation. The entrepreneurial creativity had a significant influence on competitive advantage. Creativity and innovation improved competitive advantage. Therefore, entrepreneurial creativity in the form of ambidextrous innovation becomes a competitive advantage.

Efforts to generate original creativity and significant new ventures had a positive and significant direct relationship with firm performance. Companies that manage their creativity increase their profit and turnover. Our findings support the idea that the renewal of services will improve firm performance Furthermore, this study results showed that the mediating role of ambidextrous innovation increased the influence of the relationship between entrepreneurial creativity and firm performance.

Using the model proposed in this study, it is shown that the influence of entrepreneurial creativity on competitive advantage accounted for $58 \%$ absolute contribution. This finding indicated that improving entrepreneurial creativity, ambidextrous innovation, and firm performance increases competitive advantage.

The research model was constructed using existing theories and concepts. However, there were limitations to the scope of the research. Further research is needed to explore the relationship between entrepreneurial creativity and competitive advantage for new business ventures in other types of business A further area of study that is needed is the extent to which the company has a culture of creativity and is accustomed to managing creativity in operational activities.

\section{Conclusion}

This study found that efforts to generate entrepreneurial creativity in new business ventures had no significant effect, despite having a positive relationship to competitive advantage. In contrast, the efforts to generate entrepreneurial creativity in a new business venture had a significant positive relationship with firm performance. Since new business ventures have limited resources, access to external resources, legitimacy, and reputation, new business venture's 
efforts to generate entrepreneurial activity influence firm performance, but it is not sufficient to create a competitive advantage. This study also found that a new business venture may obtain a competitive advantage through strategic actions, such as creativity management, in the form of ambidextrous innovation. This ambidextrous innovation can be a mediating factor in generating entrepreneurial creativity, reinforcing the performance and competitiveness of new business ventures.

\section{References}

Acosto, P. S., Popa, S., \& Isabel, M. C. (2019). Information technology, knowledge management and environmental dynamism as drivers of innovation ambidexterity: A study in SMEs. Journal of Knowledge Management, 22(4), 824-849. https://doi.org/10.1108/JKM-10-2017-0448

Ahlin, B., Mateja, D., \& Robert, D. H. (2013). Entrepreneurs' creativity and firm innovation: The moderating role of entrepreneurial self-efficacy. Small Business Economics, 43(1), 101-117. https://doi.org/10.1007/s11187-013-9531-7

Amabile, T. M. (1997). Entrepreneurial creativity through motivational synergy. The Journal of Creative Behavior, 31(1), 18-26. https://doi.org/10.1002/j.2162-6057.1997.tb00778.x

Andrews, J., \& Smith, D. C. (1996). In search of the marketing imagination: Factors acceting the creativity of marketing programs for mature products. Journal of Marketing Research, 33(2), 174-187. https://doi.org/10.1177\% 2F002224379603300205

Atuahene-Gima, K. (2005). Resolving the capability rigidity paradox in new product innovation. Journal of Marketing, 69(4), 61-83. https://doi.org/10.1509\%2Fjmkg.2005.69.4.61

Barriopedro, E. N., Ripol, R. R., \& Pesantez, L. B. T. (2019). Creativity: An intangible capital generating competitive quality in the Spanish advertising industry. Academy of Accounting and Financial Studies Journal, 23(2), 1-9.

Baron, R. A., \& Tang, J. (2011). The role of entrepreneurs in firmlevel innovation: The joint effects of positive affect, creativity, and environmental dynamism. Journal of Business Venturing, 26(1), 49-60. https://doi.org/10.1016/j.jbusvent.2009.06.002

Bibi, S., Asif, K., Hong-dao, Q., Garavelli, A. C., Angelo, N., \& Capolupo, P. (2020). Innovation climate, a determinant of competitiveness and business performance in Chinese Law Firms : the role of firm size and age. Sustainability, (12)12, 4948. https://doi.org/10.3390/su12124948

Carrier, C., Cossette, P., \& Verstraete, T. (1999). Experimental implementation of a new creative method to support futurology by small business in a strategic management perspective. Journal of Enterprising Culture, 8(2), 121-140. https://doi. org/10.1142/S0218495800000085

Chang, Y., \& Hughes, M. (2012). Drivers of innovation ambidexterity in small to medium size firms. European Management Journal, 30(1), 1-17. https://doi.org/10.1016/j.emj.2011.08.003
Chen, C. J., \& Huang, J. W. (2009). Strategic human resource practices and innovationperformance-the mediating role of knowledge management capacity. Journal of Business Research, 62(1), 104-114. https://doi.org/10.1016/j.jbusres.2007.11.016

Cho, M., Bonn, M. A., \& Su, J. H. (2019). Innovation ambidexterity: Balancing exploitation and exploration for startup and established restaurants and impact upon performance. Industry and Innovation Journal, 27(4), 340-362. https://doi.org/10.108 $0 / 13662716.2019 .1633280$

Damanpour, F., Richard, M. W., \& Claudia, N. A. (2009). Combinative effects of innovation types and organizational performance: A longitudinal study of service organizations. Journal of management studies. 46(4), 650-675. https://doi. org/10.1111/j.1467-6486.2008.00814.x

Eftekhari, N., \& Bogers, M. (2015). Open for entrepnereuership: How open innovation can foster new venture creation. Creativity and Innovation Management, 24(4), 574-584. https://doi.org/10.1111/caim.12136

Ferreira, J., Arnaldo, C., \& Luiz, M. (2017). Dynamic capabilities , creativity and innovation capability and their impact on competitive advantage and firm performance: The moderating role of entrepreneurial orientation. Technovation, 92(32), 102061. https://doi.org/10.1016/j.technovation.2018.11.004

Gupta, R., \& Banerjee, P. (2016). Antecedents of organizational creativity: A multilevel approach. Central and Eastern European online library, 17(2), 167-177. https://doi.org/ 10.3846/ btp. 2016.624

Hair, F. H., Anderson, R. E., \& Tatham, R. L. (2010). Multivariate data analysis with reading. New York, NY: Macmillan Publishing Company

He, Z. L., \& Wong, P. K., (2004). Exploration vs exploitation: An empirical test of the ambidexterity hypothesis. Organizational Science, 15(4), 375-497. https://doi.org/10.1287/ orsc. 1040.0078

Heunks, F. J. (1998). Innovation, creativity and success. Small Business Economics, 10(3), 263-272. https://doi. org/10.1023/A:1007968217565

Hills, G. E., Lumpkin, G. T., \& Singh, R. P. (1997). Opportunity recognition: Perceptions and behaviors of entrepreneurs. Frontiers of Entrepreneurship Research, 17,168-182.

Hoang, C. C., \& Ngoc, B. H., (2019). The relationship between innovation capability and frim's performance in electronic companies, Vietnam. Journal of Asian Finance, Economics and Business, 6(3), 295-304. https://doi.org/10.13106/jafeb.2019. vol6.no3.295

Jamshi, J., \& Ganeshkumar, C. (2017). Causal linkage among business analytics, supply chain performance and competitive advantage. KIIT Journal of management. 13(2), 29-36. http:// dx.doi.org/10.23862/kiit-parikalpana/2017/v13/i2/164518

Kharub, M., \& Rajiv, S. (2018). An integrated structural model of QMPs, QMS and firm's performance for competitive positioning in MSMEs. Total Quality Management \& Business 
Excellence, 31(2), 312-341. https://doi.org/10.1080/14783363. 2018.1427500

Kathiravan, C., Bhagavatham, P., Palanisamy, V., \& Rajasekar, A. (2019). Influence of entrepreneurial creativity on competitive adnvantage in automobile engineering and technologies industries. International Journal of Advanced Science and Technology, 27(1), 166-172.

Larraneta, B., Zahra, S. A., \& Bonzalez, J. L. G. (2012). Enriching strategic variety in new ventures through external knowledge. Journal of Business Venturing, 27(4), 401-413. https://doi. org/10.1016/j.jbusvent.2011.11.004

Lestari, S. D, Leon, F. M., Widyastuti, S., \& Brabo, N. A. (2020). Antecedent and consequences of innovation and business strategy on performance and competitive advantage of SMEs. Journal of Asian Finance, Economics and Business 7(6), 365378. https://doi.org/10.13106/jafeb.2020.vol7.no6.365

Liu, F. H., \& Huang, T. L. (2018). The influence of collaborative competence and service innovation on manufacturers' competitive advantage. Journal of Business \& Industrial Marketing, 33(4), 466-477. https://doi.org/10.1108/JBIM-122016-0294

Madzar, D., \& Ines, M. (2019). Improving business competitiveness based on managing creativity system. Ekonomska Misao I Praksa, 1, 193-208.

Muafi, M. Y., Siswanti, A. K., Diharto, S., \& Salsabil, I. (2020). Innovation culture and process in mediating human capital supply chain on firm performance. Journal of Asian Finance, Economics and Business, 7(9), 593-602. https://doi. org/10.1316/jafeb.2020.vol7.no9.593

Newbert, S. L. (2008). Value, rareness, competitive advantage and performance: A conceptual level empirical investigation of the resource-based view of the firm. Strategic Management Journal, 29(7), 745-768. https://doi.org/10.1002/smj.686

Nguyen, M. T., \& Khoa, B. T. (2020). Improving the competitiveness of exporting entreprises: A case of Kian Giang province in Vietnam. Journal of Asian Finance, Economics and Business, 7(6), 495-508. https://doi.org/10.13106/jafeb.2020.vol7.no6.495
Noor, J., Musa, A. A., \& Yaacob, M. R. (2018). Mediating entrepreneurial creativity: The effect of human resource practices on innovation. Malaysian Management Journal, 22(2018), 53-56.

Puhakka, V. (2005). The role of intellectual capital in opportunity recognition of entrepreneuers. Oulu: University of Oulu, Departement of Information Processsing Science.

Redmond, M. R., Mumford, M. D., \& Teach, R. (1993). Putting creativity to work: Effects of leader behavior on subordinate creativity. Organizational Behavior and Human Decision Process, 55(1), 120-151. https://doi.org/10.1006/ obhd.1993.1027

Samson, A. T., \& Umar, D. M. (2020). An examination of the relationship between entrepreneurial creativity and firm performance. Journal of International Business and Management, 3(2), 1-18. https://doi.org/10.37227/jibm-201904-96

Sigalas, C. (2015). Empirical investigation of balanced score's theoretical underpinnings. Journal of Accounting and Organizational Change, 11(4), 546-572. https://doi. org/10.1108/JAOC-03-2014-0024.

Sigalas, C., Pekka, E., \& Georgopoulos, N. B. (2013). Developing a measure of competitive advantage. Jounal of Strategy and Management, 6(4), 320-342. https://doi.org/10.1108/JSMA03-2013-0015

Sigalas, C., \& Papadakis, V. M. (2018). Empirical investigation of relationship patterns between competitive advantage and superior performance. Journal of Strategy and Management, 11(1), 81-111 . https://doi.org/10.1108/JSMA-01-2017-0010

Subramaniam, M., \& Youndt, M. A. (2005). The influence of intellectual capital on the types of innovative capabilities. Academy of Management Journal, 48(3), 450-463. https://doi. org/10.5465/amj.2005.17407911

Woodman, R. W., Sawyer, J. E., \& Griffin, R. W. (1993). Toward a theory of organizational creativity. Academy of Management Review, 18(2), 293-321. https://doi.org/10.5465/ amr.1993.3997517 